\title{
Resources on the Net
}

\author{
Past, Present, and Future of Academic Libraries \\ Compiled by Chris Bober, Concordia University; Montreal, Quebec, Canada
}

\section{Documenting the Past}

American Library Association. (2009). American library history: A comprehensive guide to the literature. Retrieved February 19, 2009, from American Library Association Website:

http://www.ala.org/ala/mgrps/rts/lhrt/popularresources/amerlibhis.cfm

This site features reprints of the first six chapters from the second edition of American Library History: A Comprehensive Guide to the Literature, a bibliography on the history of libraries in the United States, from the earliest times to 1986. Chapter six deals exclusively with the history of academic libraries.

American Library Association. Library History Roundtable. (2009). Bibliography of library history. Retrieved

February 19, 2009, from American Library Association Website:

http://www.ala.org/ala/mgrps/rts/lhrt/popularresources/libhistorybib/libraryhistory.cfm

The Library History Round Table publishes a bibliography of library history in each semi-annual issue of their newsletter, Bibliography of Writings on the History of Libraries, Librarianship, and Book Culture. This series is edited by Ed Goedeken, Humanities Bibliographer at Iowa State University. Geographic coverage includes libraries in the United States and Internationally. A cumulative bibliography, presented in three sections, encompasses the years19901994.

Lester, M. A. (1995, November). History of the National College of Education Libraries 1920-1978. Revised.

[Electronic version]. (ERIC Documents Reproduction Service No. ED390439).

This document traces the history of Chicago's National College of Education libraries, from its humble beginnings in 1920 to its development as a multiple branch academic library operation in 1978. In 1990, the institution became National-Louis University. As Associate Director of Libraries at the National College of Education, Lester had access to a wealth of both published and unpublished documents. She also obtained information from past and present faculty members through oral histories. The philosophies and visions of the six library directors who span this period are presented, along with the resulting changes within the libraries. Of particular interest is the section on the evolution of libraries as learning resource centers.

Libraries Today. (2008, August 21). The electronic history file: Canadian library biographies and histories. Retrieved February 19, 2009, from http://www.uoguelph.ca/ lbruce/history.shtml

This resource, first developed in February 1996, provides links to brief entries on Canadian library histories. Although the majority of the entries are for public libraries, university, college, special, and school library histories as well as biographical information on prominent individuals are well represented.

Williams, W. J. (2004, Fall). History of North Carolina libraries and librarianship: A bibliography, Part III [Electronic version]. North Carolina Libraries, 62(3), 128-179.

Williams's extensive bibliography, published in four successive volumes of North Carolina Libraries, is the only published bibliography on the library history of an entire state. Part III includes sources of library history of North Carolina colleges, universities, and community colleges. 


\section{The Present: Responding to Changing Environments}

Mack, D., Behler, A., Roberts, B., \& Rimland, E. (2007, Summer). Reaching students with Facebook: Data and best practices. E-JASL: The Electronic Journal of Academic and Special Librarianship 8(2). Retrieved February 24, 2009, from http://southernlibrarianship.icaap.org/content/v08n02/mack_d01.html

This paper sets out to investigate how librarians can effectively use Facebook and other social networking sites to communicate with students and colleagues. Data was gathered on the Facebook inquiries experienced by a librarian over the curse of one semester at Pennsylvania State. Guidelines for using Facebook as an outreach tool are also provided. The study concluded that due to "the apparent willingness of undergraduate students to communicate with librarians by means of Facebook, we recommend that library professionals whose positions require them to interact with undergraduates seriously consider making use of this service.”

OCLC. (2006).College students' perceptions of libraries and information resources. Retrieved February 25, 2009, from OCLC’s Website: http://www.oclc.org/reports/pdfs/studentperceptions.pdf

This survey is a subset of the December 2005 OCLC report Perceptions of Libraries and Information Resources. A total of 396 undergraduate and graduate students from six countries, including the United States and Canada, were surveyed as to their information-seeking habits and preferences. Also included were responses from the 14- to 17-yearold pre-college age group to provide contrast and comparison with the college students. Taken as a whole, "respondents have positive, if outdated, views of the "Library." Younger respondents—-teenagers and young adultsdo not express positive associations as frequently. These findings, and more, are valuable insights for anyone seeking to know more about the library usage and perceptions of college students and young people.”

Association of College and Research Libraries. (2007). A guide for writing CMC collection development policies. Retrieved February 19, 2009, from Association of College \& Research Libraries Website: http://staging.ala.org/ala/mgrps/divs/acrl/publications/downloadables/guidetowritingcmc.pdf

This latest set of guidelines for curriculum materials centers, prepared by members of the Curriculum Materials Committee of the Education and Behavioral Sciences Section

of ACRL, acknowledges that "technology has become an ever-present force in the areas of library collections and teaching and learning delivery methods." It was designed as an attempt "to meld traditional collection development policy requirements with the challenges of new technologies and collection formats.” The format is generalized enough to be adaptable to all types of CMC's in academic libraries. A sample collection development policy is included in Appendix $\mathrm{C}$ of the document.

Association of College \& Research Libraries, Education \& Behavioral Sciences Section, Curriculum Materials Committee. (2008, November 05). Selected Websites of importance to college/university education librarians. Retrieved February 25, 2009, from Association of College \& Research Libraries Website: http://www.ala.org/ala/mgrps/divs/acrl/about/sections/ebss/cimc/cimc.cfm

This webliography was prepared by past and present members of the Education \& Behavioral Sciences Section's Curriculum Materials Committee. It was designed specifically for educators in pre-school through college educational environments. Subject coverage includes lesson plans and teaching activities, children's and young adult literature, and instructional technology.

\section{The Future: Challenges and Opportunities for Academic Libraries}

Association of College \& Research Libraries. (2007, February 13). Changing roles of academic and research libraries. Retrieved February 24, 2009, from Association of College \& Research Libraries Website: http://www.ala.org/ala/mgrps/divs/acrl/issues/future/changingroles.cfm

This essay was the product of an ACRL Tech Summit that was held in November 2006. Summit participants were convened to address "how technologies, on the one hand, and the changing climate for teaching, learning and 
scholarship, on the other hand, will likely recast the roles, responsibilities and resources of academic libraries over the next decade.” The essay provides an action plan for academic libraries to confront these changes and to play an integral role in supporting higher education’s core missions of research and education.

Association of College \& Research Libraries. (2008, January). Environmental scan 2007. Retrieved February 24, 2009, from http://www.ala.org/ala/mgrps/divs/acrl/publications/whitepapers/Environmental_Scan_2.pdf.

This is an update to the Association's first environmental scan published in 2003. It reflects changes to the academic library environment since that time and it also reinforces long established practices. The report provides a list of emergent issues and the "Top Ten Assumptions for the Future of Academic Libraries and Librarians."

Dempsey, L. (2009, January). Always on: Libraries in a world of permanent connectivity. First Monday. 14(1).

Retrieved February 24, 2009, from

http://firstmonday.org/htbin/cgiwrap/bin/ojs/index.php/fm/article/view/2291/2070

Dempsey presents the changing social dynamics brought about by the exponential growth in the adoption of mobile communications by the latest generation of college students. Focus is then shifted to the challenges and opportunities this technology brings to academic libraries. Libraries must adapt to the needs of this new cohort and become mobileready in order to maintain their visibility. Dempsey provides examples of how libraries are currently integrating mobile communications into their institutional missions, taking into account physical spaces, reference and alerting services, and collection development.

Miller, R. (2008, August 15). Future-proof your library. Library Journal. 133(13). Retrieved February 23, 2009, from http://www.libraryjournal.com/article/CA6585850.html

Miller assembled the Library Journal's team of “Movers \& Shakers” to address the requirements that both the profession and libraries need to ensure a vital future. Many of the suggestions that are put forward involve abandoning existing practices and contain an element of risk-taking. The key to the library’s future relevance is the hiring and retention of librarians who "must be not just comfortable with change but able to lead it."

Council on Library and Information Resources. (2008, August). No brief candle: Reconceiving research libraries for the 21st Century. Retrieved February 24, 2009, from http://www.clir.org/pubs/reports/pub142/pub142.pdf

This report calls for redefining and redesigning academic libraries to meet the challenges posed by the constantly changing landscape brought about by digital technologies. Eight essays on future scenarios for libraries were prepared and distributed in advance to participants of a symposium that was convened in Washington, D.C. on February 27, 2008. The report, composed of both the essays and the proceedings of the symposium, represented the collaborative effort of librarians, university administrators, publishers, and information technology specialists. The report's recommendations "reveal a range of perspectives and questions on the transformation of libraries. Although they are presented as discrete topics, the discussions reflected their interderdependence.”

Compiler's note: Text that is enclosed within quotations marks has been taken directly from the source document.

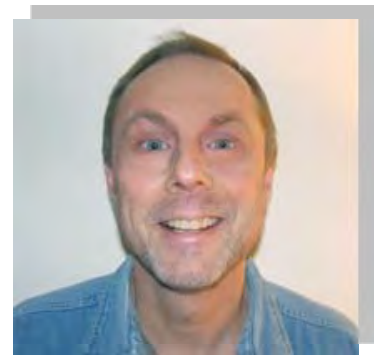

Chris Bober is the Education Librarian at Concordia University Libraries. boberc@alcor.concordia.ca 